\title{
Język maski. O funkcjach ironii w tomie Chwile Elizy Orzeszkowej
}

Magdalena Dziugieł-Łaguna 
nAPIS Seria XIV 2008

\section{Magdalena Dziugieł-Łaguna}

\section{Język maski. O funkcjach ironii w tomie Chwile Elizy Orzeszkowej}

Szminkę, którąpowlekamżycie, noszę zawsze w ręku.

Michel Leiris ${ }^{1}$

Artur Symons mówi, że:

Przedstawicielem naszego wieku jest Pierrot, namiętny, ale słaby, dopóty obnosił się ze swym szczerym i otwartym sercem, aż stwardniało w zimnym powietrzu. [...] Jest świadomy i tego faktu, że ciągle musi znajdować się na oczach publiczności, a także wie o tym dobrze, że uczucie do jego kostiumu nie pasuje. [...] aż staje się wreszcie wspaniałym fałszem... Prostota bowiem to najśmieszniejsza rzecz pod słońcem. Więc staje się wykształconym pierrotem, intelektualizuje przyjemność [...], pogrąża się w żałobnych rozmyślaniach nad tym, że przedmioty przemieniają się w groteskową radość, którą on wyrazi symbolami, zawsze posłusznymi jego rozkazom, i przystroi à la Giotto eleganckim piruetem².

Zacytowane stanowisko nie tylko oddaje klimat minionego wieku. Może stać się ono myślą przewodnią tych wszystkich czasów i tych wszystkich tekstów kultury, któ-

${ }^{1}$ M. Leiris, Ja, Pierrot, tł. T. i J. Błońscy, w: Maski, wyb., opr. i red. M. Janion, S. Rosiek, t. 1, Gdańsk 1986, s. 12.

2 A. Symons, Przedstawiciel naszego wieku, tł. R. Jabłkowska, w: ibidem, s. 11. 
re kreują swą rzeczywistość w konwencji maski - pojęcia szeroko rozumianego. Nie chodzi tu bowiem o rodzaj rytualnej maski wykorzystywanej zarówno w kulturach egzotycznych, jak i rodzimych (europejskich), dawnych i bliższych, ale o maskę mowy, której tworzywem jest oczywiście język. W tym szerokim i bogatym semantycznie pojęciu maski zawierać się będzie także ironia. Nic więc dziwnego, że nie tylko naszym czasom sekunduje Pierrot. Jako symbol pewnych postaw i zachowań jego obecność wyczuwa się u początków naszej europejskiej kultury.

W tak rozpoczętych rozważaniach pragnę postawić zasadnicze dla tematu pytania: co to jest ironia i kim jest ironista? jak Eliza Orzeszkowa wykorzystuje ironię w kreacji świata przedstawionego w cyklu Chwile, a wreszcie — jak sama pisarka ją pojmuje?

Ironia wywodzi się od greckiego słowa eironeia i w swym pierwotnym znaczeniu odnosi się do sposobu mówienia. Arystoteles definiował ją także jako pewną skłonność umysłu do odbierania rzeczywistości. Jej początki wiążą się z sokratejską metodą dociekań nad istotą dobra. Wiek XIX przeciwstawia ironii sokratejskiej ironię romantyczną, ale i w niej ówcześni myśliciele (Georg Wilhelm Friedrich Hegel, Sфren Kierkegaard) dostrzegają wyraz określonej postawy umysłu autorów. To stanowisko sytuuje ironię w różnych pozaliterackich dziedzinach, jak na przykład psychologia, chociaż według Bedy Allemana ${ }^{3}$ powinna ona być określana jako zjawisko literackie i stylistyczne.

Romantyzm pojmuje ironię jako kategorię filozoficzną i metafizyczną, służącą autoprezentacji sztuki. Przejawia się ona w swoistej grze języka, który zabarwia ją żartem, kpiną czy szyderstwem. Tę grę z językiem i z czytelnikiem podejmuje oczywiście autor od pierwszego niemal wersu tekstu, dając się jej uwieść tak skutecznie i tak ostatecznie, że każda próba odejścia od ironicznej maniery wydaje się nieprawdopodobna. W ten sposób autor ironiczny staje się więźniem wypracowanego schematu. Nic więc dziwnego, że polski pozytywizm w swej estetyce unika skrajności, co oznacza, że ucieka od schematycznie i obligatoryjnie pojmowanej ironii romantycznej w kierunku jej wysublimowanych odmian. Czymże więc jest ostatecznie ironia czy raczej jak ostatecznie da się odczytywać w dziewiętnastowiecznej prozie? Moim zdaniem należy ją traktować rzeczywiście jako zjawisko stylistyczne (a więc także językowe) i jako zjawisko literackie, wykorzystujące opozycję między przekazem prawdziwym a przekazem dosłownym. Staje się językiem poniekąd sybillicznym, bo zawiera ukryte znaczenia, które musi odczytać odbiorca, aby w pełni zrozumieć przekaz literacki. W takiej sytuacji autor staje się ironistą i czytelnik także nim jest, bo inaczej nie zauważyłby zastosowanej ironii. Twórca romantycznej koncepcji ironii, Friedrich Schlegel, powiedzial, że „dla kogoś, kto jej nie ma, pozostaje ona, nawet najszczerzej ujawniona, zagadką"4.

${ }^{3}$ Zob. B. Alleman, O ironii jako o kategorii literackiej, tł. M. Dramińska-Joczowa, „Pamiętnik Literacki” 1986 z. 1, s. 229.

${ }^{4}$ Cyt. za: P. de Man, Pojęcie ironii, tł. A. Sosnowski, „Literatura na Świecie” 1999, nr 10-11, s. 7. 
David S. Kaufer wyróżnia ironię sytuacyjną i ironię nadawcy, która wyznacza trzy role: rolę ironisty, rolę obserwatora ironii oraz rolę ofiary ironii. Zarówno teoretycy języka, jak i badacze literatury, traktując ironię jako zjawisko werbalne, stylistyczne i literackie, zwracają uwagę na obecność ironizującego podmiotu ${ }^{5}$. Wyczuć ironię, dostrzec ironiczny gest, wychwycić sarkazm, wypowiedzieć się ironicznie może tylko człowiek odpowiednio usposobiony do prowadzenia intelektualnych gier, a więc ktoś, kto także intencjonalnie i świadomie posługuje się ironią. Niezależnie od tego, czy jest ona na wzór sokratejski - maską nakładaną w dyspucie, czy jak u Teofrasta ${ }^{6}$ płaszczyzną porozumienia nadawcy z odbiorca, czy wzorem Schlegla albo Novalisa - autoironią ${ }^{7}$ (ponieważ odczuwanie konfliktu pomiędzy pozorem a prawdą rozgrywa się w obrębie własnego ,ja”), wiąże się zawsze z odczuwaniem wyższości ${ }^{8}$ wobec tych, dla których ironia jest zbędna $\mathrm{w}$ poznawaniu świata, ponieważ w przeciwieństwie do podmiotu ironizującego, obiekt ironii nie dociera do zręcznie ukrytej myśli i błędnie interpretuje słowa czy zachowania - błędnie według twórcy ironii albo jej widza.

Czy Orzeszkowa ma tę cechę duchowego arystokratyzmu potrzebną do ukazywania ironicznego obrazu rzeczywistości? Z pozoru sprawa wydaje się dość oczywista. Pisarka wywodzi się z domu o wielkich tradycjach", nie ma więc wątpliwości, że jej osobowość literacka kształtuje się pod wpływem romantyków. W takiej sytuacji dziwne byłoby, gdyby ironia jako postawa intelektualna i kategoria estetyczna była jej obca. Najprościej sięgnąć do jej osobistych wyznań, w których ujawnia nieprzeciętną wrażliwość na zadania artysty. Należą do nich służba, obowiązek i nieobecne do czasu neoromantycznego przełomu Boże posłannictwo. Potwierdzenia własnych przemyśleń na temat artysty słowa poszukuje u pisarzy różnych epok, odwołuje się do antycznych Greków i twórców renesansu (Reja ${ }^{10}$ ) i caly czas uzupełnia osobistą jego definicję. W liście do Tadeusza Garbowskiego, wspólautora $A d$ astra, tak mówi o kondycji poety:

To loteria, gra, hazard, jak wszystko inne, z tą różnicą, że nie my sami rzucamy stawki na rouge et noir, którym jest przyszłość nasza, lecz rzuca je to coś, co nas uskrzydla, różnymi czyni od ludzi innych, wzrok zabarwia inaczej $\mathrm{i}$ inne struny $[\ldots] \mathrm{w}$ duszy naciąga. Ta meta-istota, która $\mathrm{z}$ nami czy w nas na świat przyszła, rękoma naszymi rzuca stawkę [...] Czy Pan

\footnotetext{
${ }^{5}$ Zob. D. S. Kaufer, Ironia, forma interpretacyjna i teoria znaczeń, t1. M. B. Fedewicz, „Pamiętnik Literacki” 1986, z. 1, s. 316.

${ }^{6}$ Zob. W. Tatarkiewicz, Historia estetyki, t. 1, Wrocław 1960, s. 206-307.

7 Zob. A. Sandauer, Liryka i logika, Warszawa 1971, s. 364.

8 Zob. P. Łaguna, Ironia jako postawa i jako wyraz (z zagadnień teoretycznych ironii), Kraków-Wrocław 1984, s. 21.

${ }^{9}$ Zob. E. Jankowski, Eliza Orzeszkowa, Warszawa 1966, s. 18-22.

${ }^{10}$ Zob. E. Orzeszkowa, Listy zebrane, opr. E. Jankowski, t. 9: Do znajomych i przyjaciót..., Wrocław 1981, s. 56.
} 
będzie poetą pierwszorzędnym? Nie wiem [...]. Więc czy poetą będąc, a nie pisząc mniej cierpieć Pan będzie niż pisząc? Wątpię. [...] Zawsze mi się wydaje, że nie dla większego od innych szczęścia, lecz owszem dla stokroć większej sumy cierpień - ale także dla chwilowych wniebowzięć, które innym ani śnić się mogą, poeci poetami na świat przychodzą ${ }^{11}$.

Powyższe stanowisko przyjmuje artystyczny kształt w kreacjach bohaterów dojrzałej prozy autorki Chwil. Bohaterki tego tomu opowiadań są istotami „odmiennymi” (niekiedy artystkami) i ta ich odmienność wywołuje w nich postawę wyższości wobec świata. Wykorzystane w ich charakterystyce stylistyczne zabiegi (metaforyzacja) słuząa także ironicznej ocenie rzeczywistości i demaskacji sztucznego blichtru i fałszywych ról, z którymi wspomniane bohaterki muszą się zmierzyć.

Co skłania Orzeszkową do posługiwania się ironią? Jakie okoliczności stwarzają w jej prozie przestrzeń do wykorzystania tej figury stylistycznej czy tropu jako sposobu mówienia o rzeczywistości (tak określa ironię Paul de $\mathrm{Man}^{12}$ )? Czy sprawia to jej podejście do świata, jak definiuje wyżej, jako do maskarady, prowokacyjnej błazenady, gry i hazardu, które ujawniają potencjalność ironii, tworząc przestrzeń dla jej zaistnienia? ${ }^{13}$ Wydaje się jednak, że w taki sposób oceniają świat ludzie wolni, społeczności niespętane przymusem obrony narodowej tożsamości, a nie naród tyleż wybrany, co chyba przeklęty. Gra i blazenada są przywilejem wolnych:

Że Rosa Bonheur przyjmowala gości swoich w męskim szlafroku i konno siedząc na balkonie domu swego; - że genialna George Sand oblekała się od czasu do czasu w postać gamena lub awanturnicy — nie dziw! Były to córki możnego, wolnego, szczęśliwego narodu $[\ldots]^{14}-$

pisze autorka Chwil o pierwszych emancypantkach (przybierających maski) do Nikodema Erazma Iwanowskiego 1 kwietnia 1882 roku, i tym samym wyraża przekonanie, że choć źródłem wiedzy o świecie może być dialog prowadzony pomiędzy eironem a alazonem, to świadomość taka nie może wpłynąć na postawy Polaka-artysty. Życie w kraju okrytym żałobnym całunem determinuje działania „strażników świątyni narodowej", a nie błaznów sprawy narodowej:

[Artyści] umacniają podwaliny, podpierają strop, ścierają rdzę, zdzierają z okien całuny $[\ldots]$, a tłumom mówią: „trwajcie! czekajcie! pracujcie!”,

1 Op. cit., t. 3: Do literatów i ludzi nauki..., Wroclaw 1956, s. 190.

12 Zob. P. de Man, Retoryka czasowości, tł. A. Sosnowski, „Literatura na Świecie” 1999, nr 10-11,

s. $216-241$.

${ }^{13}$ Zob. P. Łaguna, Ironia..., op. cit., s. 60.

${ }^{14}$ E. Orzeszkowa, Listy zebrane, t. 9, op. cit., s. 53. 
chłoszcząc je czasem, czasem dźwigając do ruchu i życia [...]. Ludzi tych, tych stróżów świątyni jest spora gromada. Wyglądają oni różnie. Są między nimi wyżsi i niżsi, silniejsi i słabsi — ale możnaż ich wyobrazić sobie w sukniach — arlekinów? I któryż z nich ośmieliłby się urągać miejscu i chwili — dzwonkami błazeńskiej czapki? ${ }^{15}$

Tę postawę zdecydowanego obrońcy wolności przybierze Orzeszkowa szczególnie $\mathrm{w}$ polemice $\mathrm{z}$ niedojrzałą socjalistką ${ }^{16}$, agresywnie ogłaszającą nową ideologię. W tym celu wykorzysta sokratejską metodę naiwnych pytań wykazujących nonsens nowego programu godzącego w wolność narodu, który opłacil ją mogiłami bohaterów, definiowanych wzorem starożytnych jako tych, których nawiedzają bogowie ${ }^{17}$. I trzeba ironii zdarzeń, żeby u końca swojej kariery literackiej pisarka doczekała się nadanej jej przez dekadentów opinii pseudopatriotki, a lista epitetów na tym niestety się nie kończy ${ }^{18}$.

Mój Meir był Żydem, mój Cham Białorusinem, więc jestem pół-Polką, ja, która jak słynny w starożytności Klaudiusz Etruskus, który przeżył siedmiu krwiożerczych cezarów, przeżyłam dziesięciu jeneral-gubernatorów tuż pod ich okiem prowadząc dom głośnopolski i nigdy [...] jednego słowa nie wymówiwszy po rosyjsku ${ }^{19}$.

Biografia wiąże Orzeszkową z pozytywizmem, który będąc epoką głoszącą łagodne treści estetyczne, rezygnuje z jawnej groteski czy chłoszczącej ironii. Wpływ na swoistą (uproszczoną) konstrukcję świata przedstawionego oraz na stylistykę czy poetykę wypowiedzi artystycznej ma ów masowy czytelnik, do którego literatura ta jest kierowana, mimo to pisarze nie rezygnują z ironii. Przykładem są nowele Henryka Sienkiewicza: Humoreski z teki Worszytty, Szkice weglem, Bartek zwycięzca i powieści Bolesława Prusa: Lalka, Emancypantki, a także jego małe formy narracyjne. Jest ona też obecna w publicystyce epoki (Bolesław Prus, Aleksander Świętochowski). Pisarze porzucają jednak ironiczną postawę romantyków, polegającą na obmyślaniu nowych „konstelacji ironicznych”20, na rzecz tzw. ironii konstruktywnej, „tkwiącej w stosunkach między rzeczami” ${ }^{1}$. Ów

\footnotetext{
${ }^{15}$ Ibidem, s. 54.

${ }^{16}$ Op. cit., t. 6: Do pisarzy..., Wroclaw 1967, s. 101.

17 Op. cit., t. 9, s. 65.

18 Orzeszkowa w liście do Ignacego Baranowskiego (4 II 1900) pisała o modernistach: „Dykcjonarz tych panów zawiera takie niesłychane dotąd w literaturze wynalazki, jak: małpa w cylindrze na cokóle stojąca, psiak wpatrujący się w udo wieprza, nierządnicy na rogach ulic czatujący na życie" (op. cit., t. 4: Do literatów i ludzi nauki..., Wrocław 1958, s. 67).

19 Op. cit., t. 9, s. 114.

${ }^{20}$ Zob. E. Łubniewska , „Fantazy” Juliusza Stowackiego, czyli komedia na opak wywrócona, Wrocław 1985,

s. 106-183.

${ }^{21}$ B. Alleman, O ironii..., op. cit., s. 241.
} 
fakt dotyczy Orzeszkowej, która prowadząc intelektualną grę z czytelnikiem, posługuje się ironią: „Dzika piszę powoli [...] Nie jam winna, ale Dzika winna” - thumaczy się ze zbyt długiego milczenia Leopoldowi Méyetowi ${ }^{22}$, parafrazując Słowackiego z poematu $W$ Szwajcarii.

Ostatecznie powieść, o której tu mowa, otrzymuje tytuł Dwa bieguny, który nie zadowala jednak pisarki, ponieważ pozbawiony jest owej ironii, wynikającej z zaprzeczenia sugerowanych tytułem $D z i k a$ cech bohaterki - uosobienia nie tyle dzikości, co wzniosłości. Podobnie rzecz ma się z Chamem. W tytule zawarta jest binarna opozycja znaczeń ${ }^{23}$, bo tytulowy prostak ma tak naprawdę „nieprostą” naturę.

\section{Chwile, czyli o ironii sytuacyjnej}

Tom Chwile wydano nakładem Gebethnera i Wolffa w 1901 roku. Zawiera on opowiadania: Dymy. Sielanka, Porcelanka, Co mówit stary klon, Wśród kwiatów, Wesele wiesiotka, Kiedy u nas o zmroku, Moment oraz Z różnch dróg, drukowane w latach 1898-1900 w prasie krajowej i zagranicznej (w: „Słowie”, „Kurierze Codziennym”, „Kurierze Warszawskim” „Bibliotece Warszawskiej”, „Kraju”, „Gazecie Polskiej”). To szczególny moment dla autorki Melancholików, zwłaszcza rok 1898, kiedy powstają Porcelanka, Moment i Dymy — silnie osadzone w kontekście biograficznym. Od dwóch lat Orzeszkowa jest wdową po Stanisławie Nahorskim, z którym łączyło ją głębokie i trudne uczucie. Być może dlatego tak boleśnie przeżyła śmierć męża, i gdy go zabrakło, niczym nie może wypełnić pustki po nim. W takiej chwili poznaje trzydziestoletniego oficera piechoty Franciszka Godlewskiego, w którym niefortunnie ulokuje swe uczucia dojrzałej kobiety. Pisarka, mając naturę „,bierną, która w danych chwilach potrzebuje bodźców jakichś, które by myśl i imaginację rozruszały, rozpłomieniły, ku czemuś pchnęly"24, poszukuje w świecie i w związkach nie tylko potwierdzenia własnych uczuć, ale przede wszystkim impulsów do życia. Jakże często jej bohaterowie cierpią z powodu melancholii (Co mówit stary klon), odczuwanej — jak chce Zygmunt Freud - jako pustka własnego ,ja”. Czym była zatem pustka Orzeszkowej? W liście do Méyeta pisze:

nie wiem także, czy twarz moja posiada charakter kobiecości albo nie, ale we wnętrzu swoim jestem tak dalece kobietą, że ani rozkosze pracy twórczej, ani tryumfy miłości własnej nie mogą zabić we mnie jadu tej myśli: nie jestem kochaną ${ }^{25}$.

22 E. Orzeszkowa, Listy zebrane, op. cit., t. 2: Do Leopolda Méyeta, Wroctaw 1955, s. 49.

${ }^{23}$ Zob. D. S. Kaufer, Ironia, forma interpretacyjna..., op. cit., s. 315.

${ }^{24}$ E. Orzeszkowa, Listy zebrane, op. cit., t 6, s. 75.

${ }^{25}$ Op. cit., t. 2, s. 20. 
Niejednokrotnie wyznawała, że brakowało jej w życiu milości, także jako uczucia matki, która miłość do dziecka zastąpiła miłością do mężczyzny, nic więc dziwnego, że autorce Chwil stale towarzyszy poczucie fizycznej nieatrakcyjności i odrzucenia. Dlatego uczyni z miłości praidę, z której wszystkie inne biorą początek, jednocześnie ceniąc bardziej miłość należącą do sfery idealnych przeżyć, a nie zmysłowych, której fałsz ironicznie demaskuje w Porcelance. Pisarkę cechuje świadomość ironiczna, którą Piotr Łaguna określa jako

poczucie kontrastu, sprzeczności między zjawiskami świata wewnętrznego lub zewnętrznego danej jednostki oraz poczucie własnej wyższości ironizującego; przy czym uświadomiona przez jednostkę sprzeczność zostaje podporządkowana określonej idei bądź wizji świata i bytu ludzkiego ${ }^{26}$.

Paul de Man w Pojęciu ironii mówi, że jednym ze sposobów radzenia sobie z ironią jest jej zredukowanie do dialektyki w obrębie ,ja”, jest ona wtedy dystansem wobec samego siebie, a ujawnia się jako podwojenie ,ja”, które patrzy na siebie z pozycji wlasnego lustrzanego odbicia ${ }^{27}$. Orzeszkowa posiądzie tę umiejętność dopiero u schyłku życia:

W ogóle doświadczam pewnego dziwnego uczucia: zdaje mi się, że jestem zupełnie kim innym i tylko noszę imię tej istoty, która żyła tam i wówczas. [...] Coś tak głęboko złamało się we mnie, że mię rozdwoiło: tam była kobieta żywa [...], tu jest cień jaki, z rysów i z nazwiska do tamtej podobny ${ }^{28}$.

\section{Świat na opak, czyli świadomość outsidera}

Większość tekstów zebranych w tomie Chwile Anna Martuszewska interpretuje w kontekście cech parabolicznych ${ }^{29}$. Jednak ani Porcelanka, ani Zagadka, Moment czy Kiedy u nas o zmroku ich nie wykazują, choć jak się wydaje niemożność ustalenia miejsca akcji, które sprowadzone zostaje do informacji, że są to jakieś wielkie miasta polskie (Porcelanka, Zagadka) czy zagraniczne (Kiedy u nas o zmroku), albo wieś, z kolei tak odcięta od cywilizacji, że nabiera cech końca świata (Moment), a także problemy z określeniem czasu akcji (wiemy tyle tylko, że to początek wieku XX), sprzyjają procesowi

\footnotetext{
${ }^{26}$ P. Łaguna, Ironia..., op. cit., s. 25.

27 Zob. P. de Man, Retoryka czasowości, op. cit., s. 17.

${ }^{28}$ E. Orzeszkowa, Listy zebrane, op. cit., t. 2, s. 129.

29 Zob. A. Martuszewska, Mit. O parabolicznych formach pozytywistycznych, w: Kryzys czy przetom. Studia $z$ teorii i historii literatury, red. M. Lubelska, A. Łebkowska, Kraków 1994.
} 
uniwersalnej interpretacji. Sprowadza się ona do postrzegania świata jako przeszkody w realizacji ideału, w konsekwencji wizji świata kaleczącego, przed którym obronić może jedynie maska. Stanie się ona językiem Odysa, który „potrafi już posłużyć się mową po to, by zniknąc pod fasadą słów i uniemożliwić innym latwy dostęp do wnętrza"30. Według Wiktora Hugo ciało staje się maską, pod którą skrywa się prawdziwy człowiek $^{31}$. Maska Pierrota staje się doświadczeniem bohaterki Kiedy u nas o zmroku. Ale maska może stać się również punktem dojścia okaleczonej świadomości, a wówczas, jak chce Claude Lévi-Strauss, jej sens będzie tkwił w tym, co ona przeobraża, przeciw czemu przedstawia ${ }^{32}$. Ironia, przed którą broni posiadany w głębi duszy ideał, stanie się językiem rozczarowania i goryczy, nową mową bohaterki Porcelanki, która „cierpiąc na nostalgię ideału", w świecie znajduje jedynie trywialność.

Witold Gombrowicz stwierdza, że siła oddziaływania maski polega na ewokowaniu tajemnicy, która wtrąca człowieka w patos, a więc w dramat jego prawdziwej sytuacji w świecie ${ }^{33}$. W wymienionych wyżej opowiadaniach Orzeszkowej przestrzenią ujawnienia się owego dramatu będzie przeżywana przez bohaterki sytuacja rozczarowania rzeczywistością postrzeganą wzorem romantyków jako realno-idealistyczna ${ }^{34}$, ujawniającą bowiem sprzeczność między ideałem, czyli czystym duchem, takąż miłością a realnością skażoną, czyli naturą, zmysłowością wypaczającą ideal, będącą jego kaleką realizacją. Walentyna Kalińska, bohaterka Porcelanki, wyraża to słowami:

- Bylam szczerą, niech pan wierzy [...]. Tylko obudził pan we mnie głos, którego nigdy słuchać nie chciałam, któremu, ilekroć się odzywal, nakazywałam - spać. Obudzony przez pana ozwał się, ale na szczęście prędko umilkł wobec - wstydu. Nie będziemy szukali razem na zegarze świata godziny nadzwyczajnej, aby nie znaleźć najgminniejszej [P, s. 48] ${ }^{35}$.

Konsekwencją zderzenia patosu $z$ trywialnością, degradującą realizację aksjologii bohatera (pojmowaną jako świat ducha oczyszczony z instynktów) są narodziny świadomości ironicznej ${ }^{36}$. Dla Walentyny jest ona negatywnym punktem dojścia, ujaw-

\footnotetext{
${ }^{30}$ S. Rosiek, Maska mowy, w: Maski, op. cit., t. 2, s. 183.

${ }^{31}$ Ibidem, s. 403.

32 Zob. C. Lévi-Strauss, Maska nie istnieje sama $w$ sobie, tł. A. Tatarkiewicz, w: Maski, op. cit., t. 1, s. 72.

${ }^{33}$ W. Gombrowicz, Sybilliczny jezyk maski, w: ibidem, s. 16.

${ }^{34}$ Zob. Z. Łempicki, Źródła i typy realizmu niemieckiego w' XIX wieku, w: idem, Wybór pism, t. 1: Renesans, ośuiecenie, romantyzm i inne studia z historii kultury, opr. H. Markiewicz, wst. B. Suchodolski, Warszawa 1966, s. 416.

35 Wszystkie cytaty pochodzą z wydania: E. Orzeszkowa, Chwile, Warszawa 1951. Tytuły oznaczono następującymi skrótami: Porcelanka - P, Kiedy u nas o zmroku - K, Zagadka - Z, Moment - M; cyfry arabskie oznaczają numery stron.

${ }^{36}$ Zob. P. Łaguna, Ironia..., op. cit., s. 30.
} 
nieniem niemożności i bezsilności, twarzą ostateczną, rozstrzygającą, niemożliwą do zmiany ${ }^{37}$, ironia ta rodzi się z popiołów samego siebie:

Wiele czasu upłynęło. Walentyna Kalińska obudziła się z kamiennej zadumy i mętnym wzrokiem powiodła dokoła pokoju znowu pustego. Nagle wstała i wzięła w ręce szklane naczynie $z$ kwiatami. [...] Kobieta długo patrzała na zmiętą i oparzoną koronę kwiatu, aż z oczu jej ogromnie smutnych zaczęły padać wielkie krople łez, gdy usta do pobladłego korala teraz podobne zaszeptały:

— Lampę wzięła za słońce! [P, s. 49]

Przestrzeń, w której dochodzi do realizacji rzeczywistości idealnej, jest charakteryzowana w opowiadaniach jako sytuacja snu na jawie, somnabulicznego trwania w zadumie, odcinającego od bodźców zewnętrznych albo dosłownie śnienia, którego doznaje bohaterka Momentu. W marzeniu sennym, sublimującym jej skrywane pragnienia, przė̇ywa spotkanie z ukochanym mężczyzną, a więc sytuację, która nigdy nie stanie się już faktem.

- To taki cudny sen!

I jeszcze ciszej szepną:

— Cicho! Nie budźmy się z jaśminowego snu! [Z, s. 62]

Projekcja snu ujawnia nieautentyczność świata, jest sygnałem do zachowania ostrożności takiej, jaką wykazuje się wobec kłamstwa. Przestrzeń oniryczna gwarantuje bowiem możność intensywnego przeżycia duchowej rzeczywistości (ideału), ale tylko tak długo, jak trwa sen. Marzenie senne jest więc dla bohaterek Orzeszkowej edypowym nośnikiem logos phobou, wyrocznią nieszczęścia ${ }^{38}$, prowadzącą do świadomości ironicznej:

Czym jest życie? Snem cienia. Czym człowiek? Cieniem, który śni ${ }^{39}$.

Świat, w którym egzystują bohaterki, jest przestrzenią ujawniającą silne kontrasty, wynikające $z$ opozycji realnego-śnionego czy realnego-idealnego, patosu-trywialności, prawdy-kłamstwa. Celina z utworu Kiedy u nas o zmroku te dychotomiczne cechy świata ujmuje następująco:

Czy pan nie zauważyl, że wszystko na świecie im bliżej poznane, tym mniej piękne. Może jutrzenka i tęcza wydają się tak pięknymi dlatego, że są od nas tak dalekie [K, s. 139].

37 Zob. R. Gary, Ostateczny uyraz twarzy, tt. M. Braustein, A. Daniłowicz-Grudzińska, w: Maski, op. cit., t. 1, s. 60 .

${ }^{38}$ Zob. R. Girard, Bóg, człowiek i dzika bestia, tł. R. Forycki, w: ibidem, s. 100.

${ }^{39}$ E. Orzeszkowa, Listy zebrane, op. cit., t. 3, s. 131. 
Efektem tak ujawnionego świata, w którym to, co bliskie i poznane, nie gwarantuje poczucia bezpieczeństwa, owego świata na opak, jest czlowiek, który rozmija się z sobą samym, czlowiek niespójny, rozdwojony:

Takim jest człowiek! Ze stękającą zagadką najsprzeczniejszych potrzeb i pożądań przewraca się on na łożu swoich wlasnych tworzydel, nie wiedząc, na którym boku leżeć, bo każdy po swojemu boli [K, s. 128] —

wyznaje narrator Kiedy u nas o zmroku.

Niemożność zniesienia opozycji podmiotu i zagrażającego mu świata, obawa chaosu, rodzi konieczność szukania schronienia w przestrzeni maski, jest chęcią bezpiecznego ukrycia siebie, czego konsekwencją jest wkroczenie w przestrzeń kłamstwa. „Żyć na ziemi i nie kłamać niepodobna, gdyż życie i kłamstwo to synonimy" - stwierdzają bohaterowie Fiodora Dostojewskiego ${ }^{40}$, a Walentyna z Porcelanki zauważa: „Mowa ludzka zawiera w sobie mnóstwo samozwańców" [P, s. 41].

Umberto Eco w Między kłamstwem a ironiq konstatuje:

Nie ulega wątpliwości, że słowa kłamią czy przynajmniej nie mogą nigdy wyrazić wszystkiego ${ }^{41}$.

Słowa, tracąc swą przejrzystość stają się mową Odysa, a nie Achillesa, dla którego jeszcze „mówić to czynić się przezroczystym”"2.

Kłamstwo, ale także milczenie jako forma niemówienia prawdy, jest kostiumem wdzianym na użytek świata, maską dostosowania się, która jednakże obnaża nieprzystawalność podmiotu, paradoksalnie maskując go - demaskuje jednocześnie ${ }^{43}$. Bohaterka w rozmowie z Bronisławem Graniczem wyznaje:

Nie wiem już po raz który próbowałam razem ze wszystkimi iść do studni uciech, ale wody jej były tak zimne... Na balach tylko tak ziębłam... [P, s. 44]

Przyjęcie maski jest tu tak naprawdę przestrzenią walki pomiędzy trzymającym w uwięzieniu (maską) a więzionym (podmiotem) ${ }^{44}$, której wynik przesądzi o stopniu identyfikacji aktora z maską. Jednak Gaston Bachelard w Fenomenologii maski wskazuje, że:

${ }^{40}$ F. Dostojewski, Ach, obnażmy się, obnażmy się!, tł. M. Leśniewska, w: Maski, op. cit., t. 1, s. 120.

${ }^{41}$ U. Eco, Między kłamstwem a ironiq, tł. i opr. M. Woźniak, Kraków 2004, s. 34.

42 S. Rosiek, Maska mouy, w: Maski, op. cit., t. 2, s. 183.

${ }^{43}$ Zob. C. Lévi-Strauss, Rozdwojenie i maskarada, tł. K. Pomian, w: op. cit., t. 1, s. 78.

${ }^{44}$ Zob. Definicja maski, tt. R. Forycki, w: op. cit., t. 2, s. 12. 
Ukryty pod maską realną człowiek nie angażuje się naprawdę w proces udawania. Fenomenologia człowieka rzeczywiście zamaskowanego, całkowicie przebranego jest wówczas czystym zaprzeczeniem jego własnej istoty ${ }^{45}$.

Tyle tylko, że negacja samego siebie w przypadku Walentyny jest ceną nazbyt wysoką za możność bywania w świecie pokrytym patyną blichtru. Oto rodzi się więc świadomość outsidera, który z ironicznym gestem usuwa się na margines życia salonowego, a wybierając samotność, rozumianą jako ciągle uwalnianie się od więzów lączących go ze światem ${ }^{46}$, skazuje się na milczenie, poza granicą którego zaczyna się prawdziwy dramat:

Od dawna już powiedziałam szczęściu: obejdę się bez ciebie. Tylko, że życie mam puste. [...] Bywają nędze rozmaite, tylko, że dla głodu ciała każdy ma litość i pomoc, a o głodzie godzin nikt nie wie, bo ten, który go doświadcza, milczy [P, s. 46].

Szczególnie wyraziście uwidacznia się ów patos w zestawieniu punktu wyjścia z punktem dojścia dojrzewającej do ironii świadomości, doświadczanej przez Walentynę. Na początku bohaterka mówi:

Ja dziś, pisząc do pana z prośbą o przybycie, myślałam: będę szczerą. Myślałam: choć raz w życiu będę zupełnie szczerą. I wie pan? Od myśli tej uderzał we mnie blask radości [P, s. 39].

Na koniec zaś:

Zaśmiała się takim śmiechem, w jaki serce rwie się na szmaty i ciągle tak śmiejąc się mówila:

- Więc tak... tak! Zgoda dusz, patrzenie duszą w duszę, nostalgia ideału... budowanie drabiny ku gwiazdom... obrona, dobra rada... O, samozwańcy! [P, s. 48].

Pozostaje więc jedynie Baudelaire'owski śmiech objawiający wyższość nie nad człowiekiem jednak, lecz całą naturą, bo istniejący „tylko w stosunku do ludzkości, której udziałem był upadek" ${ }^{47}$.

${ }^{45}$ G. Bachelard, Fenomenologia maski, tł. B. Grzegorzewska, w: ibidem, s. 16.

${ }^{46}$ Zob. S. Rosiek, Ryzyko identyfikacji, w: op. cit., t. 1, s. 335.

${ }^{47}$ Cyt. za: P. Eaguna, Ironia..., op. cit., s. 39. 


\section{Świat jako karnawał, czyli maska Pierrota}

Bohaterki opowiadań Orzeszkowej, szczególnie Porcelanki i Kiedy u nas o zmroku, mają umiejętność patrzenia na świat jako na splot sprzeczności, głębokich opozycji, z którego laboratorium wychodzi człowiek taki sam - człowiek-paradoks:

Człowiek zresztą nie zawsze tylko szuka tego, czego nie zgubil, ale też często próbuje zgubić to, czego nie szukał [K, s. 128].

Potwierdza to także inny fragment:

Bo z ludźmi zawsze tak: dopóki ich lubić, pieścić, prosić, wszystko nie po twojemu, ale po swojemu robić będą; dopiero jak w złość wpadniesz, krzykniesz, odepchniesz, zaczną łasić się i dogadzać... [K, s. 135]

Zdolność takiego widzenia jest wynikiem dogłębnego poznania przede wszystkim samego siebie i prowadzi do świadomości, że skażenie świata dotyka również podmiot jasnowidzący:

Bo czlowiek bywa czasem zupełnie do samego siebie niepodobnym [K, s. 133] -

wyznaje gorzko Celina z Kiedy u nas o zmroku. Bohaterka staje się jakby kolejnym etapem świadomości ironicznej, nowym wcieleniem Walentyny, która ma już pewność, że jej prawdziwa twarz jest tylko dysharmonią, której świat nie akceptuje i nie potrzebując, eliminuje:

Czy pan zauważył, jak ludzie kochający rzadko współczują tym, których kochają? [...] Serce ci za czym lub po czym płacze? - to niech nie płacze! Masz wszystko, czego ci tylko potrzeba, i powinnaś być szczęśliwą, a jeżeli nie jesteś, to są kaprysy, przywidzenia [...] [K, s. 137]

Skoro światu doskwiera obraz autentycznej, bo odbijającej świadomość twarzy, koniecznością staje się przywdzianie maski, która uosabia opozycję tego, co powierzchowne z tym, co głębokie, zewnętrznego z wewnętrznym. Syntezą owych przeciwieństw w opowiadaniu Orzeszkowej jest scena karnawałowego balu, w którym odbija się świat jako wieczna maskarada, podszyta trywialnością i patosem, śmiechem i zgrzytem, pozornym uciszeniem i głębokim rozdarciem ${ }^{48}$. Ta ambiwalentna rzeczywistość znajduje wyraz w kreacji Celiny, która przywdziewa maskę Pierrota najlepiej pasującą do wizerunku świata-maskarady: 
- Jakże ci się ona podobała $\mathrm{z}$ włosami na rudo pomalowanymi?

- Bardzo jej z tym do twarzy. To dobra moda to malowanie włosów...

[...]

— Do rudych włosów trzeba twarzy bardzo bladej...

— Toteż i bielidło... [K, s. 150]

Taka kreacja bohaterki przywodzi na myśl powieść Wiktora Hugo Cztowiek śmiechu. Jak tytułowy bohater jest „dziełem sztuki”, wiecznie uśmiechniętą twarzą stworzoną przez chirurgiczny skalpel ${ }^{49}$, tak świat staje się chirurgiem wycinającym uśmiech na twarzy Celiny. Błazeński śmiech staje się maską bohaterki, formą jawnego naigrawania się ze świata, ukazania mu, czym w istocie jest:

- Pan tu sobie wintujesz i wintujesz, a nie wiesz, co tam w sali żona pańska dokazuje. Ot, wesoła kobieta! I dowcipna! Umierać ze śmiechu! Damy za mężczyzn, mężczyzn za damy! [K, s. 147]

Maska Pierrota dostarcza ochrony, użycza własnego bytu nosicielowi, który jest w stanie albo rozpadu, albo powstawania ${ }^{50}$, a nie mając własnego bytu, przyjmuje cudzy za własny. Wiecznie uśmiechnięta twarz płaczącego Pierrota ujawnia ontologiczny dramat Celiny:

Kotylionowe rumieńce zniknęły z niej bez śladu, sztuczna białość miała pozór kredowy i martwy. Ciemne obwódki, dookoła oczu powstałe, rzucały na twarz wyraz chmurny i chory. [...] Oczy wznosiła w górę ku gzymsom przeciwległych dachów, nad którymi po zimowym błękicie nieba przepływaly obłoki zaróżowione od wschodzącego kędyś słońca [K, s. 150].

Ta silnie symboliczna scena ukazuje dramatyczną walkę toczoną w gębi duszy pomiędzy trywialnością natury a idealnością światów ducha.

Jak widać, proces poznania jest dla bohaterek Orzeszkowej źródłem cierpienia, którym karmi się ironia. Jednak takie pesymistyczne odczuwanie świata przez pisarkę zostaje przełamane w kreacji bohaterki Momentu. Tajemnicza śpiewaczka, która pewnego razu zajeżdża do nędznej gospody, nagle pośród nocy wykonuje swą pieśń rozpaczy. Ów ból, który zmroził w niej instynkt życia, zostaje przekuty w piękno artystycznego aktu tworzenia, życie-ból przemienia się w pieśń-życie. Oto Sfinksowa zagadka rozwiązana przez Edypa.

${ }^{49}$ Zob. M. Janion, Maska maski, w: Maski, op. cit., t. 2, s. 402.

50 Zob. L. Navratil, Użyczenie bytu, tt. W. Grajewski, w: op. cit., t. 1, s. 80. 


\section{Chwile, czyli ironia werbalna}

Od kiedy daje się zauważyć, że ironia jest językiem maski? Może od zawsze? Stanisław Rosiek w swym komentarzu do dyskusji nad różnym wykorzystaniem maski w kulturze europejskiej mówi, że „nic tak dobrze jak mowa nie broni tych, którzy potrafią jej w specjalny sposób używać"s1. I dalej twierdzi, że to Odys był mistrzem w sięganiu po maskę mowy, „by osłonić przed innymi nazbyt przejrzyste oblicze" 52 . Tak więc mowa staje się tarczą dla tego, kto potrafi nią władać. Oczywiście, nie chodzi tu o kłamstwa, do których sięgał mityczny heros, ale o możliwości języka, które doskonale znał i które w określonych okolicznościach odsyłały do innej rzeczywistości niż ta, jaką język maskował ${ }^{53}$. Tảk właśnie jak ironia, która w opowiadaniach Orzeszkowej zawsze coś maskuje i jednocześnie coś przemyca. Maskuje gorzką wiedzę autorki o świecie, maskuje kontekst biograficzny, który literackim przedstawieniom przydaje ciemnych barw. Nie ma opowiadania w tomie Chwile, w którym bohaterom nie towarzyszy rozczarowanie z powodu czyjejś zdrady, oszustwa, zawiedzionych pragnień. Jednocześnie pisarka zdziera maski i obnaża prawdę o świecie, którego tak ona, jak jej bohaterki nie akceptują. I tu uwidacznia się rola ironii jako sposobu mówienia o świecie, a także o opiniach i emocjach bohaterów. Co ciekawe, w opisach odczuć postaci literackich pojawia się czasami słowo „ironia” jako autonomiczny termin o negatywnym zabarwieniu. Nazywa on i jednocześnie wartościuje stan ducha bohaterów. Walentyna (Porcelanka) z goryczą wypowiada się w rozmowie z Graniczem na temat przyjaźni, która powinna zwać się raczej „pajęczyną”, tak jest nietrwała i często samozwańcza. Ten stan rozgoryczenia bohater nazywa ironią („Więc i tak piękne dusze życie zaprawia ironią" - P, s. 41), którą Walentyna próbuje poskromić nadzieją — jak się okazuje płonną. Ta para pojęć „ironia” i „nadzieja” towarzyszy przeżyciom bohaterki Momentu. Po rozstaniu z mężczyzną popada w stan bolesnej ironii:

- Może to on... Ostatnie słowo myśli utonęło w krótkim śmiechu ironicznym... [...]

— Może... A ironia znowu w twarz nadziei parsknęła śmiechem...

[M, s. 167-168]

Ta literacka sytuacja aż się prosi o poszukanie dla niej odniesienia w życiu pisarki. I oto mamy taki obraz: Orzeszkowa, kobieta posunięta w latach, mająca ciemne skronie przyprószone siwizną, ciężar negatywnych doświadczeń zdrad ukochanego mężczyzny i decyzji o ślubie ze Stanisławem Nahorskim... To małżeństwo jest dla niej tak waż-

\footnotetext{
${ }^{51}$ S. Rosiek, Maska mouy, w: op. cit., t. 2, s. 182.

${ }^{52}$ Ibidem.

${ }^{53}$ Ibidem, s. 183.
} 
ne, że pisarka zamyka oczy i uszy na opinie świata i odkrywa przed nim swą słabość, na obronę ma tylko autoironię. Przyjaciół zawiadamia o planowanym zamążpójściu, nazywając je awanturą i katastrofą ${ }^{54}$, bo może podobnie jak Odys nie chce być przejrzysta? Orzeszkowa zresztą często ironizuje na swój temat. W jednym z listów pisze:

Jest fragment dramatyczny Konopnickiej, w którym, gdy w Aleksandrii Hipatię na śmierć haniebną wloką, ktoś z tłumu litością zdjęty woła: „Bodajbyś była len przędła, niewiasto!” Boże, ileż ja razy okrzyk ten do siebie zwracałam ${ }^{55}$.

W ironicznym ujęciu pewnych elementów świata zarówno rzeczywistego, dotyczącego biografii pisarki, jak i fikcyjnego, dotyczącego między innymi Chwil, autorka musi wykorzystać najbardziej elementarne tworzywo sztuki literackiej — język. Wiadomo, że Orzeszkowa - przedstawicielka „postyczniowej nocy” - mistrzowsko operuje metaforą, symbolem, alegorią i metonimią. Są to figury stylistyczne, które oddają patos poruszanych przez nią problemów, ale także oszukują cenzurę. Wprawdzie w Chwilach nie ma tematów politycznych, z których musiałaby się — jak zwykle zresztą - tłumaczyć przed carskimi urzędnikami i które należałoby ubrać w ezopową maskę, żeby tychże wywieść w pole, ale i tak wybór zastosowanych w ironii środków pozostaje taki sam.

Jako zjawisko językowe ironia jest postrzegana rozmaicie: jako figura i jako trop. W prozie Orzeszkowej jest ona raczej tropem - sposobem mówienia o rzeczywistości, nierzadko w trybie zaprzeczenia, negacji. W opowiadaniu Porcelanka najpierw występuje autoironia dotyczącą postaci, przedstawionej już wcześniej, Walentyny Kalińskiej. W rozmowie z kimś, kogo bohaterka uważa za przyjaciela, kto zresztą ma do tego tytułu wyraźne aspiracje, mówi o sobie — szczerze i z wyraźną ulgą, bowiem znalazła pokrewną duszę. Nazywa siebie „przewróconą głową” (w tym wypadku ironia ma charakter pragmatyczny: jest naganą, która implikuje pochwałę) i „na zegarze świata szuka godziny, której zapewne wcale nie ma” [P, s. 46]. Mamy tu do czynienia $\mathrm{z}$ metaforą o zabarwieniu ironicznym, użytą przez bohaterkę w autocharakterystyce. W gorzkim zakończeniu tej tak ładnie rozpoczętej konwersacji Walentyna znowu przywołuje tę samą myśl, tyle że teraz służy ona ironicznej, a nawet szyderczej demaskacji samozwańczego przyjaciela:

Nie będziemy szukali razem na zegarze świata godziny nadzwyczajnej, aby nie znaleźć najgminniejszej... [P, s. 48].

W obu przypadkach użycia tej samej metafory zastosowała Orzeszkowa zaprzeczenie, które pełni inne funkcje.

${ }^{54}$ Zob. E. Orzeszkowa, Listy zebrane, op. cit., t. 2, s. 57.

55 Op. cit., t. 9, s. 191. 
W teoretycznych rozważaniach nad ironią podkreśla się jej antyfrastyczną strukturę. Beda Alleman mówi, że podstawowa definicja akcentuje przejrzystą opozycję między tym, co jest dosłowne, a tym, co jest naprawdę powiedziane ${ }^{56}$. W opowiadaniach Chwile nie znajdziemy „czystych” antyfraz, po pierwsze dlatego, że jest to język silnie zmetaforyzowany (zawsze trochę niejasny, nieprzejrzysty), po drugie dlatego, że pisarka, posługując się językiem metaforyczno-symbolicznym, operuje raczej drwiną, kpiną czy nawet szyderstwem ${ }^{57}$, co jest zwerbalizowaniem faktu ironii sytuacyjnej:

1. kpina wyrażona hiperbolą — fragment rozmowy bohaterów Kiedy u nas o zmroku:

— Ciemny pogląd na ludzi! — zauważyłem. [...] A pan myśli, że to są jasne anioły? - zapytała [K, s. 135].

2. szyderstwo wyrażone wyliczeniem i stopniowaniem, też w funkcji hiperboli wypowiedź narratora:

Sarabanda, sabat, obrządkowy szał konwulsjonistów [K, s. 148].

3. drwina wyrażona peryfrazą w rozmowie bohaterów Porcelanki:

— Słyszałem, jak mąż pani uczynki miłosierne nazywa...

Premiami, udzielanymi niedołęstwu... [P, s. 45].

Jak widać w przytoczonych fragmentach uzycie ironii nie ma charakteru antyfrazy, niemniej pełni podobną rolę — sugeruje pewne ukryte sensy, sygnalizuje wartościowanie i to zwykle ujemne, jest maską języka w kreowaniu świata przedstawionego i ukazaniu myśli bohaterów.

\section{Podsumowanie}

Czasy, których zmienność wpływa na kształt i treść literatury, określają również podejście do zjawiska ironii. Towarzyszy ono kulturze niemal od początków jej istnienia. Stanowiąc z początku przedmiot i narzędzie rozważań filozoficznych, przechodzi następnie do sfery zjawisk psychologicznych i etycznych — jako cecha umysłu i jako metoda w dociekaniu, czym jest dobro. Czasami jest narzędziem groteski i maskarady, często towarzyszy przedstawieniom satyrycznym, aż do pierwszej połowy XIX wie$\mathrm{ku}$, który przyznaje ironii pierwszeństwo w sposobach wyrażania prawdy o świecie, w kreacjach narratorów i bohaterów. I wydawać by się mogło, że wraz z romantyzmem wyczerpują się możliwości estetyczne ironii. Odtąd staje się ona własną karykaturą.

\footnotetext{
${ }^{56}$ B. Alleman, O ironii..., op. cit., s. 232.

57 Zob. C. Kerbrat-Orecchioni, Ironia jako trop, tł. M. Dramińska-Joczowa, „Pamiętnik Literacki” 1986, z. 1, s. 305.
} 
Skoro nie ma ani twórcy, ani dzieła od niej wolnego, ironia popada w skostnienie. Tym można tłumaczyć ostrożne podejście polskiego pozytywizmu do wykorzystania ironii jako podstawowego elementu w kreacji świata prozy, ale to nie znaczy, że ten okres w ogóle do niej nie sięga, czego dowodem są omawiane Chwile Orzeszkowej.

Ironia nie jest celem samym w sobie w prozie autorki Porcelanki. Jako sposób prezentowania świata przedstawionego w dużym stopniu wspóluczestniczy w jego kreacji. Zjawisko ironii układa się w tej prozie w piętra znaczeń; trudno orzec, które $\mathrm{z}$ nich odgrywa decydującą rolę $\mathrm{w}$ ostatecznej wymowie dzieła, ale można pokusić się o stwierdzenie, że w strukturze świata przedstawionego ironia występuje w wymiarze egzystencjalnym, sytuacyjnym i językowym. Jak rozmaite są maski oraz ich wykorzystanie w różnych kulturach świata, tak rozmaite są możliwości wykorzystania ironii. Temat ironii nie wyczerpuje się w pierwszej połowie XIX wieku. Jest to zjawisko historyczne, a jego dialektyka uzależniona jest także od pokoleniowej zmiany warty. Im bardziej Orzeszkowa zbliża się do modernistycznych tendencji w kreacji świata, tym bardziej jej ironia nabiera ekspresji, tym bardziej zabarwiona zostaje goryczą, a nawet szyderstwem, które są wypadkową zderzenia dawnych i nowych ideałów. 